\title{
THE ARBITRATION CASE BETWEEN PHILIPPINES AND CHINA OVER THEIR DISPUTE IN THE SOUTH CHINA SEA
}

\author{
Lowell Bautista \\ Australian National Centre for Ocean Resources and Security (ANCORS), \\ Faculty of Law, Humanities and the Arts, University of Wollongong, Australia \\ (lowellbautista@gmail.com)
}

\begin{abstract}
:
This paper will examine the arbitration case filed by the Philippines against China over the West Philippine Sea on 22 January 2013. The first part, and by way of introduction, will provide a concise summary of the competing territorial and maritime jurisdictional claims over the South China Sea highlighting recent developments. The second part will discuss the system of dispute settlement under the 1982 United Nations Convention on the Law of the Sea as well as relevant international jurisprudence and State practice. The third part will examine the arbitration case in greater detail discussing its factual antecedents and the specific reliefs sought by the Philippines. In the final part, the paper will conclude with an evaluation and analysis of the arbitration case in the context of its potential implications to the management of conflict and resolution of the sovereignty disputes in the South China Sea.
\end{abstract}

Keywords: South China Sea, West Philippine Sea, law of the sea, international law, arbitration

\section{Introduction}

On 22 January 2013, the Philippines instituted arbitral proceedings against China under Annex VII of the 1982 United Nations Convention on the Law of the Sea (UNCLOS) in respect of their maritime jurisdictional dispute in the South China Sea. The arbitration is the first international litigation initiated by a claimant state in the South China Sea. It is clear that this bold move is a game changer. The proceedings have altered the terrain of strategies available to the claimant states, which has always eschewed legal options. More importantly, the decision of the Tribunal will have significant, lasting and far-reaching implications affecting the 
legal rights of all the claimant states and will strongly impact the management and resolution of the conflicting claims in the South China Sea.

The arbitration was initiated by the Philippines after a series of increasing aggressive behavior and provocative actions including a tense standoff in April 2012 between the Philippines and China over Scarborough Shoal (Bajo de Masinloc) which brought tensions in the South China Sea to their highest level since the 1994 Mischief Reef incident (Bautista, 2013). China has made it abundantly clear that it does not accept the arbitration initiated by the Philippines and has refused to participate in the proceedings. The non-participation of China's will affect neither the legitimacy of the proceedings or the validity of the judgment (Article 9, Annex VII, UNCLOS).

The strategic imperatives behind the institution of compulsory arbitration by the Philippines are evident. The legal track appears to be a logical option given the stark economic and military asymmetry between the Philippines and China. The Philippines insists, and quite rightfully, that arbitration is a peaceful, open and friendly mechanism allowing for a final, rules-based and enduring resolution to the disputes in the South China Sea in accordance with international law. China has assailed the arbitral case and vehemently refuses to participate in the proceedings, insisting instead to manage the dispute through regional mechanisms and bilateral negotiations. Despite the objections of China and its decision not to participate, the arbitration will continue.

This paper will examine the arbitration case filed by the Philippines against China over the West Philippine Sea on 22 January 2013. The first part, and by way of introduction, will provide a concise summary of the competing territorial and maritime jurisdictional claims over the South China Sea highlighting recent developments. In the second part, the paper will cover a discussion of the system of dispute settlement under the 1982 United Nations Convention on the Law of the Sea as well as relevant international jurisprudence and State practice. The third part will examine the arbitration case in greater detail discussing its factual antecedents and the specific reliefs sought by the Philippines. The final part, the paper will conclude with an evaluation and analysis the arbitration case in the context of its potential implications to the management of conflict and resolution of the sovereignty disputes in the South China Sea.

\section{Brief overview of the South China Sea dispute}

The competing claims over the West Philippine Sea are part of the longstanding territorial and maritime jurisdictional disputes in the South China Sea. In Philippine law, the West Philippine Sea refers to the maritime areas on the western side of the Philippine archipelago including the Luzon Sea as well as the waters around, within and adjacent to the Kalayaan Island Group and Bajo De Masinloc, 
also known as Scarborough Shoal (Bautista, 2013; Section 1, Administrative Order No. 29, 2012). The 2009 Philippine Archipelagic Baselines Law asserts that the Philippines exercises sovereignty and jurisdiction over both the Kalayaan Island Group and Bajo de Masinloc, under the Regime of Islands, consistent with Article 121 of UNCLOS (Section 2, Republic Act No. 9522, 2009). The renaming of the South China Sea as the West Philippine Sea bears no legal implications with respect to the claims of sovereignty over the disputed area or over the insular features found therein as well the maritime entitlements they could potentially generate. Undeniably, it does however carry a very strong patriotic assertion of sovereignty with positive psychological and propaganda value to a domestic audience. In this paper, the terms West Philippine Sea and South China Sea, as well as Bajo de Masinloc and Scarborough Shoal, will be used interchangeably.

The South China Sea is a semi-enclosed sea (Articles 122 and 123, UNCLOS) encompassing an area of around 3,500,000 $\mathrm{km}^{2}$ surrounded by the countries of Southeast Asia. The South China Sea encompasses a portion of the Pacific Ocean stretching roughly from Singapore and the Strait of Malacca in the southwest, to the Strait of Taiwan in the northeast. The sea is bordered by Borneo to the south; China and Taiwan to the north; Vietnam, Thailand and Peninsular Malaysia to the west, and the Philippines to the east. It encompasses a continuation of the Pacific Ocean stretching roughly from Singapore and the Straits of Malacca in the southwest, to the Straits of Taiwan (between Taiwan and China) in the northeast.

The South China Sea Islands is an archipelago of over 250 islands, atolls, cays, shoals, reefs, and sandbars, most of which have no native inhabitants. The islands of the South China Sea can be further subdivided into four subarchipelagos, listed by area size: (1) The Spratly Islands; (2) the Macclesfield Islands; (3) the Paracel Islands; and (4) the Pratas Islands. The majority of the disputed islands are located in the Paracel and Spratly Island chains (Bautista, 2007, p. 704). The area is the subject of competing claims among the following claimant-States: People's Republic of China (China), Republic of China (Taiwan), Vietnam, Malaysia, Brunei, and the Philippines. There are some analysts who include Indonesia as a possible seventh claimant-state. However, while Indonesia does not claim any of the islands in the South China Sea, Chinese and Taiwanese claims in the South China Sea extend into Indonesia's Exclusive Economic Zone (EEZ) and continental shelf, encroaching upon Indonesia's Natuna archipelago. There are some authors, notably Chinese scholars, who do not regard Taiwan as a claimant-state since its status as a State is disputed in international law, but merely as a province of China.

The greater number of these islands are partially submerged islets, rocks, and reefs that are little more than navigational hazards not suitable for habitation. All the claimant-States, with the exception of Brunei, have established military 
garrisons over some of features in the disputed area. In 2009, the number of features occupied in the South China Sea are as follows: Vietnam (21), the Philippines (9), China (7), Malaysia (5), and Taiwan (1) (Schofield \& Storey, 2009, p. 10).

In brief, the disputes over the South China Sea fall into three broad categories. The first category involves the competing sovereignty claims over territory, in particular over the numerous island features in the area. Second, the overlapping maritime jurisdictional zones among the littoral States of the South China Sea, which have not been delimited. The third concerns the potential maritime zones to be generated from the island features once the sovereignty issue over the same has been settled.

The dispute over the South China Sea is a complex issue primarily revolving around international law, but also involves geopolitical, regional economic, international relations considerations. A detailed discussion of the various claims over the South China Sea is beyond the scope of this Opinion. There is however extensive academic literature on this topic (See for example, Beckman, 2013; Beckman \& Schofield, 2014; Dupuy \& Dupuy, 2013; Gao \& Jia, 2013).

The six claimant-States that have overlapping and conflicting claims over the South China Sea all base their claims on principles of international law, both customary and conventional, and in particular on provisions of the UNCLOS. These principles are principally discovery and effective occupation (Bautista, 2007, p. 700). In 2014, the United States Department of State analysed the maritime claims of China in the South China Sea, and concluded that "its dashed- line claim does not accord with the international law of the sea" (p. 24).

\section{Recent developments}

It is profoundly counterintuitive to assert but in reality, despite the popular depiction in academic literature and on media, the South China Sea is relatively peaceful. However, the significant escalation in tensions in the South China Sea in recent years is undeniable. The arbitration case filed by the Philippines should be viewed from the broad context of assertive and provocative actions from claimant states over the years.

In April 2012, the standoff between the Philippines and China over Scarborough Shoal brought tensions in the South China Sea to their highest level since the 1994 Mischief Reef incident. The incident started on April 8, 2012, after eight Chinese fishing vessels anchored inside the lagoon of the Shoal were spotted by a Philippine Navy surveillance plane and confirmed by the Philippine Navy warship BRP Gregorio Del Pilar on the same day. On April 10, 2012, following established rules of engagement, a boarding team aboard BRP Gregorio del Pilar was dispatched to inspect the Chinese fishing vessels, collect photos and their 
catch. On the part of the Philippine boarding team, the apprehension of the Chinese fishermen was regarded as a routine maritime law enforcement operation which has been customary in Bajo de Masinloc. The Philippine boarding team, after inspection of the fishing vessels, discovered large amounts of illegally collected corals, giant clams and live sharks inside the first vessel. The arrest of the Chinese fishermen was blocked by two Chinese maritime surveillance ships, China Marine Surveillance 75 (Zhongguo Haijian 75) and China Marine Surveillance 84 (Zhongguo Haijian 84) (Dawnay, 2012; Department of Foreign Affairs, 2012; Inquirer Research, 2012; Santos, 2012).

On 11 April 2012, in order to de-escalate the tension, the Philippines replaced its surface combatant vessel with two civilian ships from the Coast Guard and the Bureau of Fisheries. On its part, China deployed its largest and most advanced patrol vessel equipped with machine guns, light cannons and electronic sensors, the Yuzheng 310 (de Castro, 2013). During the height of the standoff, in May 2012, there were at least 80 Chinese fishing vessels in Bajo de Masinloc. In July 2012, weather conditions brought about by a typhoon compelled the Philippines to pull-out which effectively left the shoal under the de facto control of the Chinese (Bonnet, 2012, p. 5). The retaliatory actions of China against the Philippines during the standoff included punitive economic measures such as the imposition of a travel ban on Chinese tourists travelling to the Philippines, severe restrictions on the importation of bananas from the Philippines and the announcement of a unilateral fishing ban in the South China Sea covering the shoal (Thayer, 2012). There were also other widespread rhetoric and propaganda from the Chinese alluding to the possibility of armed conflict erupting with veiled threats of using force against the Philippines (Bonnet, 2012, p. 5; de Castro, 2013, p. 7). In July 2012, for the first time in its 45-year history, the Association of Southeast Nations (ASEAN), failed to issue a joint communiqué following its annual foreign ministers meeting in Phnom Penh, Cambodia, over intense disagreement whether the communiqué should reflect the confrontation between the Philippines and China over Scarborough Shoal (Bower, 2012).

In September 2013, the Philippines released aerial surveillance photographs which showed about 75 concrete blocks allegedly installed by China on Bajo de Masinloc, which China denies. The Philippines was apprehensive that these concrete blocks could be used as platforms or foundations of larger structures in the area (Agence France-Presse, 2013). The Philippines declared plans to consider removing the concrete blocks allegedly installed by China on Bajo de Masinloc as well as filing a diplomatic protest (Dalangin-Fernandez, 2013). However, in October 2013, Philippine President Aquino disclosed that the blocks shown in the photographs were "very old" and "not a new phenomenon", with some of them have barnacles attached to them" (Mogato, 2013). 
Another contentious feature in the South China Sea is Ayungin Shoal (otherwise referred to as Second Thomas Shoal or Ren'ai Reef) which is located 105 nautical miles of the Philippine island of Palawan and lies entirely within the Philippine Exclusive Economic Zone. The Shoal is occupied by the Philippines through a small contingent of marines based on BRP Sierra Madre, a commissioned Philippine naval vessel which ran aground in 1999. In March 2014, the Philippines officially filed a diplomatic protest over the actions by the Chinese Coast Guard that prevented the delivery of supplies to the Filipino soldiers in Ayungin Shoal. The Philippines asserts that Ayungin Shoal is part of its continental shelf and over which it should enjoy sovereign rights and jurisdiction (Department of Foreign Affairs, 2014).

In August 2014, at the 47th ASEAN Foreign Ministers' Meeting in Nay Pyi Taw, Myanmar, the joint communiqué included a section on regional and international issues which focused on the South China Sea:

We remained seriously concerned over recent developments which had increased tensions in the South China Sea and reaffirmed the importance of maintaining peace, stability, maritime security as well as freedom of navigation in and over-flight above the South China Sea....

We urged all parties concerned to exercise self-restraint and avoid actions which would complicate the situation and undermine peace, stability, and security in the South China Sea and to settle disputes through peaceful means, without resorting to the threat or use of force, including friendly dialogue, consultations and negotiations, in accordance with universally recognised principles of international law, including the 1982 United Nations Convention on the Law of the Sea (Paragraphs 149 and 151, ASEAN Joint Communique, 2014).

The joint communiqué also noted the Triple Action Plan introduced by the Philippines (Paragraphs 155, ASEAN Joint Communique, 2014) which advocates a moratorium on specific activities that escalate tension in the South China Sea and underscores the imperative to pursue settlement mechanisms that will bring a final and enduring resolution to the disputes based on international law, such as the arbitration filed by the Philippines against China over the West Philippine Sea.

\section{Dispute Settlement within the framework of UNCLOS}

The dispute resolution mechanism integrated into the UNCLOS is both complex and innovative (Bautista, 2014, pp. 387-382). The compulsory adjudicative procedures in UNCLOS are a sharp departure from traditional international 
dispute settlement where consent of the parties is normally required before the submission of a dispute to arbitration or adjudication (Klein, 2009, p. 2). It is considered a central pillar of the convention and part of the delicate compromises included in the "package deal" of negotiations that led to the adoption of UNCLOS in 1982 (Adede, 1987, p. 241). In order to preserve this delicate balance, UNCLOS clearly prohibits States from making any reservations or exceptions (Article 309, UNCLOS). According to Klein, "No additional form of consent is required once a State is party to the Convention - consent to be bound by UNCLOS includes consent to compulsory procedures entailing binding decisions (subject to Sections 1 and 3 of Part XV). Under Section 2, the States in dispute do not need (both or all) to consent to the referral of the dispute to court or tribunal, but the dispute can be submitted at the behest of just one of the disputant States" (2009, p. 53).

The dispute settlement system under UNCLOS is contained in Part XV of the Convention. The provisions of Part XV are only applicable when there is a 'dispute' and it relates to either the 'interpretation' or 'application' of the Convention (Article 286, UNCLOS). In addition to the requirement that there is a dispute, the dispute must be 'legal' or 'justiciable' in that it must be capable of being settled by the application of principles and rules of international law (Lauterpacht, 2011, p. 64). Furthermore, Article 293 of UNCLOS states that the court or tribunal having jurisdiction shall apply the Convention and "other rules of international law not incompatible with this Convention." The dispute settlement regime in Part XV of UNCLOS is comprised of 3 sections. Section 1 contains the general provisions concerning dispute settlement; Section 2 outlines the compulsory procedures entailing binding decisions, and Section 3 provides for the limitations and exceptions to the applicability of Section 2.

The question of what constitutes a legal dispute is an old and enduring question but not exactly a perplexing question in international law (Amerasinghe, 2009, pp. 46-47). There have been several international cases in the Permanent Court of International Justice (PCIJ) and the International Court of Justice (ICJ) which squarely addressed this issue such as the 1924 PCIJ case of Mavrommatis Palestine Concessions between Greece and Great Britain and the ICJ decisions in the Case Concerning Military and Paramilitary Activities in and against Nicaragua between Nicaragua and the United States of America and the 2004 ICJ Advisory Opinion in the Legal Consequences of the Construction of a Wall in the Occupied Palestinian Territory, and indeed by a number of scholars. The PCIJ definition enunciated in the Mavrommatis Palestine Concessions case, that a 'dispute is a disagreement on a point of law or fact, a conflict of legal views or of interests between two persons (1924 PCIJ (Ser. A) No. 2, p. 11) and the ICJ's ruling in the Interpretation of the Peace Treaties with Bulgaria, Hungary and Romania, Advisory Opinion of 30 March 1950, as 'a situation in which the two sides held 
clearly opposite views concerning the question of the performance or nonperformance of certain treaty obligations,' (1950 ICJ Rep. 65, p. 74) have been widely adopted by other international tribunals (Schreuer, 2008, p. 960).

The issue of whether a dispute exists is in fact a crucial one and of particular relevance to the discourse of disputes in Southeast Asia, especially in the context of the strong nationalist rhetoric utilized in the disputes over the South China Sea. China, for instance, has repeatedly claimed that it exercises "indisputable sovereignty" over the South China Sea (Dillon, 2011, p. 54; To, 1999, p. 166). In principle, a dispute which is purely political without any legal connotations is not justiciable and cannot be taken cognizance of by any international court or tribunal. In fact, in actual practice, parties to a dispute refute the existence of a dispute for the purpose of contesting the jurisdiction of an international court or tribunal (Schreuer, 2008, p. 959). In the case of UNCLOS, if a dispute arises whether a court or tribunal has jurisdiction, that court or tribunal is vested with the power to resolve the issue (Article 288, UNCLOS). It is well to remember that a dispute hardly ever presents itself as a purely legal question, and often, raises both legal as well as political issues. This is true for most of the territorial and maritime disputes in Southeast Asia. These disputes not only test the limits of the dispute settlement provisions of UNCLOS but also restrain the parties from considering international adjudicative processes as a viable alternative to resolve their longstanding unresolved territorial and maritime issues.

\section{The compulsory and binding nature of the UNCLOS dispute settlement regime}

The dispute settlement mechanism provided under the legal framework of UNCLOS establishes a compulsory and binding framework for the pacific settlement of all ocean-related disputes (Rayfuse, 2005, pp. 683-711; Sheehan, 2005, pp. 165-190). UNCLOS in Part XV requires States Parties to settle any dispute between them concerning the interpretation or application of the Convention by peaceful means in accordance with Article 2 (3), of the UN Charter "in such a manner that international peace and security, and justice, are not endangered." States parties are supposed to seek a solution by any of the means indicated in Article 33 (1), of the UN Charter, that is, through "negotiation, inquiry, mediation, conciliation, judicial settlement, resort to regional agencies or arrangements, other peaceful means of their choice."

UNCLOS gives primacy for States to reach an agreement on the basis of international law in order to achieve an equitable solution in the delimitation of the EEZ and continental shelf between States (Article 74(1) and 83(1), UNCLOS). However, when States have been unable to reach agreement within "a reasonable 
time," the States concerned are obliged to resort to the procedures in Part XV of the Convention (Articles 74(2) and 83(2), UNCLOS).

More importantly, submission to the compulsory procedures is not automatic since States may still reserve the right under Article 298 to have certain specified categories of disputes exempted from the compulsory fora. In such an instance, compulsory conciliation becomes the default procedure where Article 298(1)(a) operates to exempt a State or a dispute from compulsory adjudication. However, this only applies in a limited circumstance and the conciliation itself does not create a binding result. Thus far, it has never been initiated.

The optional exceptions to the compulsory procedure in Article 298 show the clear intention to remove maritime boundaries delimitation disputes from compulsory judicial settlement. These elaborate mechanisms are designed to preserve the sovereignty of States by giving the State parties the freedom to choose the manner by which they will settle their differences (See and compare, Annex V, Article 3; Annex VI, Article 4; Annex VII, Article 3; and Annex VII, Article 3, UNCLOS; Adede, 1977; Treves, 1999).

The dispute settlement mechanism within the framework of UNCLOS clearly creates an obligation among the claimant countries to settle their conflicting claims peacefully by any means of their own choice (Article 280, UNCLOS). However, McDorman asserts that the dispute settlement procedure of UNCLOS is not part of customary law and, thus, is only binding upon those states which are parties to UNCLOS (2000, p. 259). Furthermore, the principle of peaceful settlement of international disputes operates on the basis of the sovereign equality of States, a fundamental premise upon which the whole architecture of international law operates. This implies that as a subject of international law, every State is equal to every other State, regardless of size, or even economic or political power. It is also independent and cannot be compelled to participate in any legal procedure without its consent (Anand, 1966; Armstrong, 1920; Brown, 1915).

The compulsory settlement mechanism within the framework of UNCLOS is triggered only as an option where the parties are not able to settle their differences by peaceful means of their choice (Article 286, UNCLOS). But, even then, the submission of a dispute to such a forum depends on the willingness of the parties. In this regard, the dispute resolution mechanism may appear to offer no progress over previous regimes. This is actually not the case. In international law there is really no judicial forum with compulsory jurisdiction. Any form of third party dispute resolution is founded upon the assent of the parties involved. The lack of compulsion to submit to compulsory judicial forums under UNCLOS is neither a serious drawback nor does it fall short of legitimate expectations. The UNCLOS dispute settlement regime improves upon the Optional Protocol system in the sense that in the case of the former, States become automatically bound by the compulsory procedures upon ratification of UNCLOS; whereas under the 
latter, States become bound only when they become parties to the Protocol. Nonetheless, ultimately, this means still that the dispute settlement regime of UNCLOS is only as good as the claimant States are willing to formally invoke it.

\section{The choice of procedure in UNCLOS disputes}

UNCLOS provides the general rule that any dispute concerning the interpretation or application of the Convention, provided no settlement has been reached by the parties using any peaceful means of their choice, is subject to the system of compulsory procedures entailing binding decisions in Section 2, Part XV of UNCLOS (Article 286, UNCLOS). This is, of course, subject to the limitations and exceptions to the applicability of Section 2 of Part XV as specified in Section 3 of Part XV (Articles 297 and 298, UNCLOS). The parties to a dispute have the obligation to exchange views (Article 283, UNCLOS) and to exhaust local remedies where this is required by international law (Article 295, UNCLOS).

If a settlement has not been reached, UNCLOS stipulates that the dispute be submitted at the request of any party to the dispute to a court or tribunal having jurisdiction in this regard (Article 286, UNCLOS). UNCLOS defines those courts or tribunals as: (a) the International Tribunal for the Law of the Sea (established in accordance with Annex VI of the Convention) including the Seabed Disputes Chamber; (b) the International Court of Justice; (c) an arbitral tribunal constituted in accordance with Annex VII of the Convention; and (d) a special arbitral tribunal constituted in accordance with Annex VIII for one or more of the categories of disputes specified therein (Article 287, UNCLOS). The availability of a variety of forums was a compromise to secure consensus during the negotiations for the compulsory dispute settlement provisions of UNCLOS (Charney, 1996, p. 71).

UNCLOS gives the State party the freedom to choose, by means of a written declaration submitted when signing, ratifying or acceding to the convention or at any time thereafter, one or more of the above courts or tribunals (Article 287(1), UNCLOS). If States Parties to a dispute have accepted the same procedure, the dispute will be referred to that procedure, unless the parties agree otherwise (Article 287(4), UNCLOS). If a State party to a dispute is not covered by a declaration in force, it shall be deemed to have accepted arbitration under Annex VII (Article 287 (3), UNCLOS). If the States Parties to the dispute have not accepted the same procedure, the dispute may only be submitted to arbitration under Annex VII, unless the parties agree otherwise (Article 287(5), UNCLOS). 


\section{Limitations and exceptions to compulsory binding dispute settlement}

The prohibition upon States parties to make any reservations or exceptions to the Convention under Article 309 necessitated that exceptions and limitations had to be allowed in the compulsory dispute settlement regime of UNCLOS, which is provided for in Section 3 of Part XV of UNCLOS. These basically cover matters which are considered of vital national concern to a State to oblige it to submit to any binding dispute settlement regime (Klein, 2009, p. 122). Specifically, there are two categories of disputes which are not covered by the compulsory procedures entailing binding decisions specified in Section 2: first, disputes with respect to discretionary decisions on permits for marine scientific research by a coastal State; (Article 297(2), UNCLOS) and secondly, disputes with respect to discretionary decisions on fisheries in a coastal State's EEZ (Article 297(3), UNCLOS). The first category of dispute is subject to conciliation under Annex $\mathrm{V}$ except questions relating to exercise of coastal State to designate specific areas or withhold consent in accordance with Article 246(6) and Article 246(5), respectively. The second category includes its discretionary powers for determining the allowable catch, its harvesting capacity, the allocation of surpluses to other States and the terms and conditions established in its conservation and management laws and regulations.

Section 3 of Part XV also allows States to declare in writing that it does not accept any of the procedures in Section 2 for certain categories of disputes. The State may do this when signing, ratifying or acceding to UNCLOS or at any time thereafter (Article 298 (1), UNCLOS). States may exclude the following disputes from the compulsory procedures entailing binding decisions in Section 2: disputes concerning the interpretation or application of Articles 15, 74 and 83 on maritime boundary delimitation, or those involving historic bays or titles; (Article 298 (1)(a)(i), UNCLOS) disputes concerning military activities; disputes concerning law enforcement activities in respect of rights and jurisdiction exercised by the coastal State over its EEZ resources; and disputes where the UN Security Council is exercising functions under the UN Charter (Article 298(1)(c), UNCLOS).

\section{Philippine arbitration against China over West Philippine Sea}

\section{Institution of arbitral proceedings}

On 22 January 2013, the Philippines instituted arbitral proceedings against China under Article 287 and Annex VII of UNCLOS in order "to clearly establish the sovereign rights and jurisdiction of the Philippines over its maritime entitlements in the West Philippine Sea" (Republic of the Philippines, 2013. Hereinafter, Notification and Statement of Claim). On 19 February 2013, China rejected and returned the Philippine Notification through a Note Verbale in which it described "the Position of China on the South China Sea issues". The Permanent Court of 
Arbitration based in the Hague, the Netherlands, serves as the Registry for the arbitration. The Arbitral Tribunal, composed of five members, is chaired by Judge Thomas A. Mensah of Ghana, along with Judge Jean-Pierre Cot of France, Judge Stanislaw Pawlak of Poland, Professor Alfred Soons of the Netherlands, and Judge Rüdiger Wolfrum of Germany (Permanent Court of Arbitration First Press Release, 2013).

On 11 July 2013, the Arbitral Tribunal held its first meeting at the Peace Palace in the Hague. On 27 August 2013, the Arbitral Tribunal issued its first Procedural Order, establishing the initial timetable for the arbitration and adopting its Rules of Procedure. The Tribunal gave the Philippines until 30 March 2014 to submit its Memorial fully addressing "all issues, including matters relating to the jurisdiction of the Arbitral Tribunal, the admissibility of the Philippines' claim, as well as the merits of the dispute". The Tribunal provided the Philippines and China the opportunity to comment on the draft Rules of Procedure before the Rules of Procedure and timetable were adopted. The Philippines submitted comments on the draft on 31 July 2013 whilst China addressed a Note Verbale to the PCA on 1 August 2013 reiterating its position that "it does not accept the arbitration initiated by the Philippines" and stating that it was not participating in the proceedings (Permanent Court of Arbitration First Press Release, 2013).

On 30 March 2014, the Philippines submitted its Memorial which addressed both issues of jurisdiction and the merits of its claim. The Philippine Memorial consisted of 10 volumes and nearly 4,000 pages in length (Department of Foreign Affairs, 2014). While the contents of the Memorial remains confidential at this stage, the Arbitral Tribunal may direct that the written pleading be published. (Article 16 (1), Rules of Procedure of the Arbitral Tribunal, 2013). The Arbitral Tribunal in its Procedural Order No. 2 has set 15 December 2014 as the deadline for China to submit its Counter-Memorial in response to the Philippine Memorial. On 7 December 2014, China issued a position paper reiterating its previous arguments that "the Arbitral Tribunal manifestly has no jurisdiction over the present arbitration" and "China's rejection of and non-participation in the present arbitration stand on solid ground in international law" (China, Position Paper, 2014).

\section{Factual background}

The Philippines asserts that China's claim to "sovereignty" and "sovereign rights" over the maritime area within its so-called "nine dash line" encompassing virtually the entire South China Sea has interfered with the rights of the Philippines under UNCLOS over its own exclusive economic zone and continental shelf, in violation of UNCLOS (Notification and Statement of Claim, paragraph 2). In addition, China has seized control and occupied several small, uninhabitable coral projections, submerged features and protruding rocks barely above water at high 
tide, as well as claimed maritime zones surrounding these features greater than 12 nautical miles (Notification and Statement of Claim, paragraphs 4 and 14). Among these features include Mischief Reef, McKennan Reef, Gaven Reef and Subi Reef, which are at best low tide elevations and part of the Philippine continental shelf or the international seabed (Notification and Statement of Claim, paragraphs 14 to 19). The Philippines alleges further that China has also seized the following features in the Spratly Islands: Johnson Reef, Cuarteron Reef and Fiery Cross Reef, which it considers as "submerged reefs with no more than a few rocks protruding above sea level at high tide" (Notification and Statement of Claim, paragraph 31).

In essence, the Philippines is arguing, first, that these submerged features in the South China Sea which are not above sea level at high tide, are not islands under the Convention. Secondly, these submerged features are part of the seabed and subject to the regime of the continental shelf under Part VI of the Convention and cannot be acquired by a State or subject to its sovereignty since they are not located in a coastal state's territorial sea. Third, since these submerged features are not above sea level at high tide, nor are they located on China's continental shelf, the occupation of China of these submerged features is unlawful under the Convention. Fourth, the features which remain above water at high tide qualify as "rocks" under Article 121(3) of the Convention which only generate an entitlement of a maximum 12-nautical territorial sea and anything beyond this is unlawful under the Convention, as China has claimed over the features. Lastly, China's exploitation and prevention of the Philippines from exploiting the living and nonliving resources in the Philippines' EEZ and continental shelf, as well as the interference with the exercise by the Philippines of its navigational rights over these waters, are all unlawful under the Convention (Notification and Statement of Claim, paragraph 31).

In relation specifically to Bajo de Masinloc, the Philippines alleges that in 2012, "China seized six small rocks that protrude above sea level within the Philippines' exclusive economic zone, unlawfully claimed an exaggerated maritime zone around these features, and wrongfully prevented the Philippines from navigating, or enjoying access to the living resources within this zone, even though it forms part of the Philippines' EEZ." (Notification and Statement of Claim, paragraph 20). As stated above, the Philippines asserts that the insular features of Bajo de Masinloc are "rocks" under Article 121(3) of UNCLOS; yet, "China unlawfully claims entitlements to maritime zones greater than $12 \mathrm{M}$ in the waters and seabed surrounding them, and wrongfully excludes the Philippines and other States from these areas" (Notification and Statement of Claim, paragraph 24). Thus, in Bajo de Masinloc, "the maritime zones claimed by China unlawfully encroach upon the Philippines' 200 M exclusive economic zone and continental shelf extending from Luzon and Palawan, and prevent the Philippines 
from enjoying its rights under the Convention within $200 \mathrm{M}$ (Notification and Statement of Claim, paragraph 24).

\section{Jurisdiction of the Tribunal}

UNCLOS, in Part XV, establishes a system of compulsory binding dispute settlement (CBDS) for any dispute relating to the interpretation or application of any provision of the Convention. Therefore, in principle, a dispute between two States parties on the interpretation or application of a provision in UNCLOS, allows one party to the dispute to unilaterally invoke the CBDS system in Part 2 of Part XV (UNCLOS, Article 286). UNCLOS includes consent in its text. This is clear from the provisions of 74, 83, 186-191, 226, 264-265, 279-299, 309, 318. Annexes V, VI, VII, VIII. Article 309, on reservations and exceptions, provides that "No reservations or exceptions may be made to this Convention unless expressly permitted by other articles of this Convention" (For academic literature on the dispute settlement regime under UNCLOS, see, Adede, 1987; Klein, 2005).

Both the Philippines and China being parties to UNCLOS, subject to specified exceptions provided in the Convention, are bound by the regime of dispute settlement system (See, UNCLOS, Articles 287 (1), 298 (1) and 310). The Philippines asserts that the claims in the arbitration have been the subject of good faith negotiations and numerous exchange of views thereby satisfying Articles 279 and 283 of UNCLOS, requiring States parties to settle disputes by peaceful means in accordance with the United Nations Charter and the requirement for parties to proceed expeditiously to an exchange of views regarding a settlement by negotiation or other peaceful means, respectively (Notification and Statement of Claim, paragraphs 8, 25 to 30; Article 279 and 283(1), UNCLOS).

The failure of the Philippines and China to settle their dispute by peaceful means of their own choice, allows recourse to any of the procedures in Part XV, including compulsory procedures entailing binding decisions in Section 2 of Part XV, (Article 281(1), UNCLOS) by submission to a tribunal having jurisdiction by the request of any party (Article 286, UNCLOS). A State party is allowed the choice of compulsory procedure, (Article 287(1), UNCLOS) with arbitration under Annex VII as the default procedure when the parties to a dispute have not accepted the same procedure (Article 287(5), UNCLOS). Thus, since both the Philippines and China have not made any declaration, the instant dispute may only be submitted to arbitration in accordance with Annex VII (Article 287(5), UNCLOS).

UNCLOS allows States parties to declare in respect of certain specified categories kinds of disputes are excluded from the application of the compulsory binding procedures for the settlement of disputes under the Convention. (Section 3 of Part XV, UNCLOS). China submitted a Declaration on 25 August 2006 under Article 298 of UNCLOS, which states that "The Government of the People's 
Republic of China does not accept any of the procedures provided for in Section 2 of Part XV of the Convention with respect to all the categories of disputes referred to in paragraph 1 (a) (b) and (c) of Article 298 of the Convention" (China, Declaration, 2006). The Philippines is aware of the Chinese Declaration and has avoided raising subjects or claims that China has, by virtue of that Declaration, excluded from arbitral jurisdiction (Notification and Statement of Claim, paragraph 8). The Philippines does not seek in the arbitration, "a determination of which Party enjoys sovereignty over the islands claimed by both of them. Nor does it request delimitation of any maritime boundaries" (Notification and Statement of Claim, paragraph 7). Specifically, the Philippine claims are excluded from the Chinese Declaration, "because they do not: concern the interpretation or application of Articles 15, 74 and 83 relating to sea boundary delimitations; involve historic bays or titles within the meaning of the relevant provisions of the Convention; concern military activities or law enforcement activities; or concern matters over which the Security Council is exercising functions assigned to it by the UN Charter" (Notification and Statement of Claim, paragraph 40).

\section{Relief Sought}

The Philippine arbitration case against China over the West Philippine Sea asks the Tribunal three fundamental questions. First, whether "the Parties' respective rights and obligations in regard to the waters, seabed and maritime features of the of the South China Sea are governed by UNCLOS, and that China's claims based on its "nine-dash line" are inconsistent with the Convention and therefore invalid." Second, whether "under Article 121 of UNCLOS, certain of the maritime features claimed by both China and the Philippines are islands, low tide elevations or submerged banks, and whether they are capable of generating entitlement to maritime zones greater than 12M." And lastly, whether the Philippines should be allowed "to exercise and enjoy the rights within and beyond its exclusive economic zone and continental shelf that are established in the Convention" (Notification and Statement of Claim, paragraph 6).

In terms of specific relief sought, the arbitration enumerates the following:

1. Declares that China's rights in regard to maritime areas in the South China Sea, like the rights of the Philippines, are those that are established by UNCLOS, and consist of its rights to a Territorial Sea and Contiguous Zone under Part II of the Convention, to an EEZ under Part V, and to a Continental Shelf under Part VI;

2. Declares that China's maritime claims in the South China Sea based on its so-called "nine dash line" are contrary to UNCLOS and invalid; 
3. Requires China to bring its domestic legislation into conformity with its obligations under UNCLOS;

4. Declares that Mischief Reef and McKennan Reef are submerged features that form part of the Continental Shelf of the Philippines under Part VI of the Convention, and that China's occupation of and construction activities on them violate the sovereign rights of the Philippines;

5. Requires that China end its occupation of and activities on Mischief Reef and McKenna Reef;

6. Declares that Gave Reef and Subi Reef are submerged features in the South China Sea that are not above sea level at high tide, are not islands under the Convention, and are not located on China's Continental Shelf, and that China's occupation of and construction activities on these features are unlawful;

7. Requires China to terminate its occupation of and activities on Gaven Reef and Subi Reef;

8. Declares that Scarborough Shoal, Johnson Reef, Cuarteron Reef ad Fiery Cross Reef are submerged features that are below sea level at high tide, except that each has small protrusions that remain above water at high tide, which are "rocks" under Article 121(3) of the Convention and which therefore generate entitlements only to a Territorial Sea no broader than 12 $\mathrm{M}$; and that China has unlawfully claimed entitlements beyond 12M from these features;

9. Requires that China refrain from preventing Philippine vessels from exploiting in a sustainable manner the living resources in the waters adjacent to Scarborough Shoal and Johnson Reef, and from undertaking other activities inconsistent with the Convention at or in the vicinity of these features;

10. Declares that the Philippines is entitled under UNCLOS to a $12 \mathrm{M}$ Territorial Sea, a 200 M EEZ, and a Continental Shelf under Parts II, V, and VI of UNCLOS, measured from its archipelagic baselines;

11. Declares that China has unlawfully claimed and has unlawfully exploited the living and non-living and non-living resources in the Philippines' EEZ and Continental Shelf and has unlawfully prevented the Philippines from exploiting living and non-living resources within its EEZ and CS;

12. Declares that China has unlawfully interfered with the exercise by the Philippines of its rights to navigation and other rights under the Convention in areas within and beyond 200 M of the Philippines' archipelagic baselines; and

13. Requires that China desist from these unlawful activities (Notification and Statement of Claim, paragraph 41). 


\section{Conclusion}

The arbitration case by the Philippines against China over the West Philippine Sea should be viewed as a positive development in the context of its potential implications to the management of conflict and resolution of the sovereignty disputes in the South China Sea. The overlapping territorial and maritime claims in the South China Sea will remain as possible flash points of intermittent lowlevel conflict and continuing sources of tension in the region. However, the arbitration case filed by the Philippines is groundbreaking in its attempt to move the agenda forward by attempting a lawful, peaceful, and rules-based mechanism through a neutral, independent and impartial platform. Whilst many have criticized the legal move as foolhardy, it is in fact, a logical and pragmatic option and a calculated risk. It is understandable to anticipate that the legal move of the Philippines may imperil its bilateral relations with China. However, in the longterm, this should not be the case. Overall, the broadly positive trend in PhilippineChina diplomatic and economic relations will continue.

The highly complex legal issues related to the case are beyond the scope of this paper. However, at the outset, the critical threshold legal question is whether the case filed by the Philippines is properly subject of arbitration. The answer to this is clearly in the affirmative. The right of the Philippines to institute compulsory arbitration is incontrovertible (Article 286, UNCLOS). The refusal of China to participate in the proceedings will not impair the arbitration. The UNCLOS Annex VII arbitral procedure is so designed that even the failure of a party to take the requisite action will not frustrate the arbitral proceedings. The non-participation of China in both the written and oral proceedings of the Arbitral Tribunal will both have no bearing on the process of the proceedings and the validity of the arbitral award (Article 9, Annex VII, UNCLOS). The Arbitral Tribunal only needs to satisfy itself that it has jurisdiction and that the claim of the Philippines is well founded in fact and law (Article 9, Annex VII, UNCLOS).

There is no duty for China to appear before the Tribunal. However, it does have the duty to comply with the decision of the Tribunal, (Article 11, Annex VII, UNCLOS) provided it has jurisdiction. (Section 2, Part XV, UNCLOS). Its nonappearance will not affect the validity of the judgment. It is also final and there is no provision for appeal, since an appellate procedure has been not been agreed in advance by the parties. (Article 11, Annex VII, UNCLOS) The decision of China not to take part in the proceedings means that it will not have the opportunity to submit evidence to substantiate its claim and to present contrary evidence against the factual allegations of the Philippines. However, despite its non-appearance, China remains a party to the arbitration case and may at any time choose to participate or exercise any of its procedural rights, as long as they are not barred by time. 
This arbitration is not a mere legal contest between the Philippines and China. It would be a disservice to the international community to view this case from this narrow perspective. The case raises profound issues which will have lasting impact on the other claimant states in the South China Sea and the rest of the world. In principle, the award of the tribunal is made on behalf of the community of nations because in a broad sense, a claim made by any nation over a piece of territory is actually a claim against the rest of the world. In this sense, a baseless claim or one that violates recognized international norms and rules undermines the system. Thus, an adjudication by an international tribunal concerning issues of territorial sovereignty is a declaration that such a claim is valid and binding against the rest of the world or community of nations. Without this declaration, the issue remains unsettled and the competing parties are left to their own devices to assert, defend, and strengthen their claims, sometimes with disastrous consequences for everyone. If this case brings clarity or resolves some prejudicial issues even without determining with finality the issue of ownership of the features, which is not the aim of the arbitration, then, it would have served its purpose.

The ruling of the arbitral tribunal will definitely carry enormous precedential weight. The composition of the panel - two were former presidents of ITLOS, with three currently sitting as ITLOS judges - will make its ruling hard to ignore. Despite the lack of a coercive force to enforce judicial awards in the international law, it is crucial that there is public confidence in the process. A crucial part of this is participation in international processes as well as respect for decisions, awards and judgments of international adjudicative and judicial bodies. It will not serve China's strategic interests and its proper place in the global diplomatic stage to ignore or defy the ruling of the Tribunal.

\section{References}

Adede, A. O. (1977). Law of the sea: The scope of the third party, compulsory procedures for settlement of disputes. American Journal of International Law, $71,305-311$.

Adede, A.O. (1987). The System for Settlement of Disputes under the United Nations Convention on the Law of the Sea. Dordrecht: Martinus Nijhoff.

Administrative Order No. 29. (2012). Naming the West Philippine Sea of the Republic of the Philippines, and for other purposes, 5 September 2012.

Agence France-Presse (2013). Philippines says it finds more Chinese blocks on reef". Interaksyon (September 4, 2013). Retrieved on 5 November 2014, from: http://www.interaksyon.com/article/70057/philippines-says-it-findsmore-chinese-blocks-on-reef. 
Amerasinghe, C. F. (2009). Jurisdiction of specific international tribunals. Leiden: Martinus Nijjhoff.

Anand, R. P. (1966). Sovereign equality of states in international law. International Studies, 8, 213-241.

Armstrong, S. W. (1920). The Doctrine of the equality of nations in international law and the relation of the doctrine to the treaty of Versailles. The American Journal of International Law, 14, 540-564.

ASEAN Joint Communique (2014). Nay Pyi Taw, Myanmar, 13 November 2014. Retrieved on 5 November 2014, from, http:/www.asean.org/images/documents/47thAMMandRelatedMeetings/J oint\%20Communique\%20of\%2047th\%20AMM\%20as\%20of\%209-8$14 \% 2010 \% 20$ pm.pdf.

Bautista, L. (2007). Thinking outside the box: The South China Sea issue and the United Nations Convention on the Law of the Sea (Options, Limitations and Prospects). Philippine Law Journal, 81, 699 - 731.

Bautista, L. (2013). The Philippine claim to Bajo de Masinloc in the context of the South China Sea Dispute. Journal of East Asia and International Law, 6, 497529.

Bautista, L. (2014). Dispute settlement in the law of the sea convention and territorial and maritime disputes in Southeast Asia: Issues, opportunities, and challenges. Asian Politics and Policy, 6(3), 375-396.

Beckman, R. (2013). The UN Convention on the Law of the Sea and the maritime disputes in the South China Sea. American Journal of International Law, 107, 142-163.

Beckman, R., \& Schofield, C. (2014). Defining EEZ claims from islands: A potential South China Sea change. International Journal of Marine and Coastal Law, 29, 193-243.

Bonnet, F. X. (2012). Geopolitics of Scarborough Shoal. Irasec's Discussion Papers No. 14, November 2012.

Bower, E. (2012). China reveals its hand on ASEAN in Phnom Penh. East Asia Forum (July 28, 2012). Retrieved on 5 November 2014, from, http://www.eastasiaforum.org/2012/07/28/china-reveals-its-hand-onasean-in-phnom-penh/.

Brown, P. M. (1915). The theory of the independence and equality of states. The American Journal of International Law, 9, 305-335.

Charney, J. (1996). The implications of expanding international dispute settlement systems: The 1982 convention on the Law the Sea. American Journal of International Law, 90, 69-75.

China, Declaration (2006). Declaration made after ratification on 25 August 2006. Declarations and statements, United Nations Division for Ocean Affairs and the Law of the Sea. Retrieved on 5 November 2014, from. 
http://www.un.org/depts/los/convention_agreements/convention_declarat ions.htm.

China, Position Paper (2014). Ministry of Foreign Affairs. Position paper of the government of the People's Republic of China on the matter of jurisdiction in the South China Sea arbitration initiated by the Republic of the Philippines, 7 December 2014. Date retrieved 8 December 2014, from, http://www.fmprc.gov.cn/mfa_eng/zxxx_662805/t1217147.shtml.

Dalangin-Fernandez, L. (2013). Philippines to file another diplomatic protest vs China over Scarborough structures. InterAksyon (September 5, 2013). Retrieved on 5 November 2014, from, http://www.interaksyon.com/article/70097/philippines-to-file-anotherdiplomatic-protest-vs-china-over-scarborough-structures.

Dawnay, K. (2012). The Scarborough Shoal standoff. Current Intelligence (May 17 2012). Retrieved on 5 November 2014, from, http://www.currentintelligence.net/analysis/2012/5/17/the-scarboroughshoal-standoff.html.

De Castro, R. (2013). China's realpolitik approach in the South China Sea dispute: The case of the 2012 Scarborough Shoal standoff. Managing Tensions in the South China Sea Conference, Center for Strategic and International Studies, 5-6 June 2013.

Department of Foreign Affairs (2012). Philippines asserts sovereignty over Panatag (Scarborough) Shoal, Official Gazette (April 11, 2012). Retrieved on 5 November 2014, from, http://www.gov.ph/2012/04/11/philippines-assertssovereignty-over-panatag-scarborough-shoal/.

Department of Foreign Affairs (2014). Statement of secretary Albert F. del Rosario on the submission of the Philippines' memorial to the arbitral tribunal, 20 March 2014. Retrieved on 7 November 2014, from, https:/www.dfa.gov.ph/index.php/2013-06-27-21-50-36/dfa-releases/2460statement-of-secretary-albert-f-del-rosario-on-the-submission-of-thephilippines-memorial-to-the-arbitral-tribunal.

Dillon, D. R. (2011). Countering Beijing in the South China Sea. Policy Review, 167, 51-67.

Dupuy, F. \& Pierre-Marie D. (2013). A legal analysis of China's historic rights claim in the South China Sea. American Journal of International Law, 107, 124-141.

Gao, Z., \& Jia, B. B. (2013). The nine-dash line in the South China Sea: History, status, and implications. American Journal of International Law, 107, 98-124.

Inquirer Research (2014). Scarborough shoal standoff: A timeline. Inquirer (May 9, 2012). Retrieved on 5 November 2014, from, http:/globalnation.inquirer.net/36003/scarborough-shoal-standoff-ahistoricaltimeline/. 
Klein, N. (2005). Dispute settlement in the UN convention on the law of the sea. Cambridge: Cambridge University Press.

Klein, N. (2009). Dispute settlement in the UN convention on the law of the sea. Cambridge, England: Cambridge University Press.

Lauterpacht, H. (2011). The function of law in the international community. Oxford: Oxford University Press.

Mavrommatis Palestine Concessions (Greece v. Great Britain), Judgment of 30 August 1924, 1924 PCIJ (Ser. A) No. 2.

McDorman, T. L. (2000). Global ocean governance and international adjudicative dispute resolution. Ocean and Coastal Management, 43, 255 -275.

Mogato, M. (2013). Manila backtracks on South China Sea accusation against China, October 23, 2013. Retrieved on 5 November 2014, from, http://www.reuters.com/article/2013/10/23/us-philippines-southchinaseaidUSBRE99M0A720131023.

Permanent Court of Arbitration First Press Release. (2013). Arbitration between the Republic of the Philippines and the People's Republic of China: Arbitral tribunal establishes rules of procedure and initial timetable. The Hague, 27 August 2013.

Rayfuse, R. G. (2005). The future of compulsory dispute settlement under the law of the sea convention. Victoria University of Wellington Law Review, 30, 683711.

Republic Act No. 9522 (2009). An act to amend certain provisions of Republic Act No. 3046, as amended by Republic Act No. 5446, to define the archipelagic baseline of the Philippines and for other purposes, March 10, 2009.

Republic of the Philippines (2013). Department of Foreign Affairs. Notification and Statement of Claim, Manila, 22 January 2013.

Rules of Procedure of the Arbitral Tribunal (2013). Permanent court of arbitration (PCA) case no. 2013-19, the Republic of the Philippine versus the People's Republic of China, 27 August 2013.

Santos, T. (2012). PH, Chinese naval vessels in Scarborough Shoal standoff. Philippine Daily Inquirer (April 11, 2012). Retrieved on 5 November 2014, from, http://globalnation.inquirer.net/32341/ph-chinese-naval-vessels-inscarborough-shoal-standoff.

Schofield, C., \& Storey, I. (2009). The South China Sea dispute: Increasing stakes and rising tensions. Washington, D.C.: The Jamestown Foundation.

Schreuer, C. (2008). What is a legal dispute? In I. Buffard, et al (Eds.), International law between universalism and fragmentation Festschrift in honour of Gerhard Hafner (959-980). Netherlands: Brill.

Sheehan, A. (2005). Dispute settlement under UNCLOS: The exclusion of maritime delimitation. University of Queensland Law Journal, 24, 165-190.

Thayer, C. (2012). Standoff in the South China Sea: Scarborough Shoal standoff reveals blunt edge of China's peaceful rise, YaleGlobal (12 June 2012). Retrieved on 5 
November 2014, from, http://yaleglobal.yale.edu/content/standoff-southchina-sea.

To, L. L. (1999). The South China Sea: China and multilateral dialogues. Security Dialogue, 30, $165-178$.

Treves, T. (1999). Conflicts between the international tribunal for the Law of the Sea and the international court of justice. New York University Journal of International Law and Policy, 31, 809-821.

United Nations Convention on the Law of the Sea, 1833 UNTS 3, opened for signature 10 December 1982, Montego Bay, Jamaica (entered into force 16 November 1994).

United States Department of State (2014). Limits in the seas No. 143, China: Maritime claims in the South China Sea. 